\title{
精神と身体に障害をもつ人のリハビリノテシションー現状と課題一
}

\section{5. 東大リハビリテーション部における精神科デイホスピタルの実際}

\author{
東京大学医学部付属病院リハビリテーション部 古川 俊一
}

東大 DH（デイホスピタル）は，入院に変わる治療の場として昭和 49 年 1 月に開設されて から現在まで約 30 年間に 477 名を受け入れて, 主に統合失調症圈の患者の社会参加を推進す る為のリハビリテーション医療を行っている. 今回は当院での活動の実際と実例を示して, 精神障害を持つ人への精神科リハビリテーションがどのように行われているのかを明らかに する.

精神科のデイケア施設は，精神科単科病院併設あるいは診療所併設型，総合病院併設型， 保健所，独立施設など多用である．なかでも大学病院で精神障害者デイケアを行っているの は，全国でも 17 カ所のみである (H 13 年厚生労働省調査). 当院のデイホスピタルは日中だ けの部分入院施設という位置づけにあたる．医療機関に併設されていることから精神症状悪 化の際に薬物調整が容易であり, 症状をコントロールことも目指して, その特徵を生かした 運営がなされている。

対象は，統合失調症をはじめとする精神障害者であって，発病後の期間とは関係なく，対 人関係に問題を抱えており社会復帰が阻害されている方である. 統合失調症の幻覚妄想や活 動性低下など症状の有無は問わない. ただし通所施設の為，何とか来所可能な方が対象とな る. 家族の希望が強くとも自らの通所意欲がなければ継続することは出来ない. 利用年齢上 限は特に定めていないが，就労や作業所などへの適応を目指した 20 代から 30 代が中心であ り，利用者平均年齢は 27 歳である。現在在籍は 41 名で，疾患内訳として統合失調症圈が 38 名と圧倒的に多く, うち 2 名は精神発達遅滞の合併がある.

プログラムとしては, SST (生活技能訓練), 家族心理教室, 症状自己管理モジュールなど を導入している，その他に日常プログラムとしては料理やゲーム・スポーツ，軽作業，茶話 会が行われている.さらに就労が可能な方には就労援助として, 個別に職安・職場への同行 までを行う。スタッフは, きめ細やかな対応をするために医者, 看護師, 作業療法士, 臨床 心理士に研修生を加えた計 9 名体制で実施している。

当日は，実際のプログラムの利用によって改善した具体例を提示の上，その治療効果につ いて検討する.さらにデイホスピタルを終了した後の生活について，その長期転帰を示して 通過施設としてのデイケアの限界についても検討出来ればと考えている. 